\title{
Richard Wall - a personal tribute
}

Even historians who have a predisposition towards counting, as did Richard Wall, recognize that there are aspects of the human condition that defy tabulation. In this brief tribute, this celebration of the life of our Founding Editor, we endeavour to present both the quantitative and the qualitative. We offer an impressive 'census-like enumeration' of his publications, the lens through which outsiders came to view and respect Richard in the course of a career that spanned more than four decades; also, we ponder and reflect upon aspects of his personal life (sadly shorter than we all had a right to expect) that seem shrouded and mysterious even to his closest colleagues and friends.

Others will, of course, have their own reveries. Mine commences as follows. I first met Richard around the 'Library' table at the Cambridge Group, his preferred venue for entertaining the multitude of foreign visitors who arrived in Cambridge with yet another household listing that demanded analysis. There he partook of coffee and tea because, I would in retrospect argue, it allowed him to indulge in what was his true passion, sweets. A big heart and a generous nature (for what further individual academic accomplishment could he have achieved if he had not selflessly donated his own time to the mentoring of others?) are often accompanied by a large sweet tooth; which of us can recall a meal with Richard in which he passed on dessert? Enmeshed in academic conversation fuelled by biscuits (and on birthdays and the arrival of transatlantic visitors the coveted cakes from Fitzbillies), Richard Wall held court at 27 Trumpington Street like the sultan of household studies that he surely was.

It should come as no surprise that Richard, the historian of the family par excellance, was devoted to his brood. In his own parlance, Richard 
was himself a 'head of household'. In his life course, he raised two separate families and leaves children, stepchildren and grandchildren. At one time or another in his life, Richard's residence pattern encompassed nearly all the Hammel-Laslett permutations in household form including the rarely discerned frérèche. He co-resided not infrequently in multigenerational households extended in almost every imaginable direction, frequently with lodgers (but invariably without servants) in that beautiful, albeit disorderly, but above all endearing fashion that was the measure of this extraordinary man.

To the familial domain we can add the political. Richard was old Labour to the core: for the third-quarter of the twentieth century occasional Briton like myself that means Wilson and Callaghan, not Blair and Brown. No designer suits and pretentiously styled haircuts (affectations which he beyond doubt regarded as insidious as privatization) for him, though who could deny that when Richard reinvented his personal life with Beatrice Moring more than a decade ago, the beard he sported at her behest suited him well. Indeed Richard came to resemble the folksingers whom he listened to without fail (though inevitably drenched in the ubiquitous July downpours that plagued the event) each year at his much beloved Cambridge Folk Festival.

Perhaps my first personal encounter with Richard was of Wall the political activist. In those fateful months in 1979, the disastrous election looming, Richard presided at a strategy meeting at E-2 Bishops' Hostel with Peter Laslett (of Laslett and Wall, but as Peter himself was quick to point out the first volume on the household was followed by a second, Wall and Laslett) in tow preparing an offensive of massive proportions to get out the vote in the Arbury Estates for Martin Smith, the Labour candidate for Cambridge City. True to his roots, Richard was also devoted to the Co-operative movement, a tireless director of the Cambridge Co-operative and, as Continuity and Change's sound financials illustrate, devoted to its bank.

About two years ago, Richard was diagnosed with the illness to which he succumbed. He fought this diabolical menace courageously and fiercely with his beloved and devoted Beatrice in constant attendance and also bore it with a patient shrug. To the end, he never abandoned either his dignity or that peculiar glint in his eye and ironical smile. Much of what preoccupied Richard over the course of time that remained to him was to ensure the continuation of Continuity and Change. I met with him the penultimate Saturday of his life in Addenbrooke's Hospital, and the conversation turned, as it inevitably had for nearly thirty years, to submissions past, present and future. The journal will survive him, and will prosper, but it will never be quite the same without him. If there is 
consolation in this tragic event it is that three times a year, when the journal hits the streets, lands on desks and thumps on doormats (or arrives electronically), he will be remembered.

\section{Lloyd Bonfield}

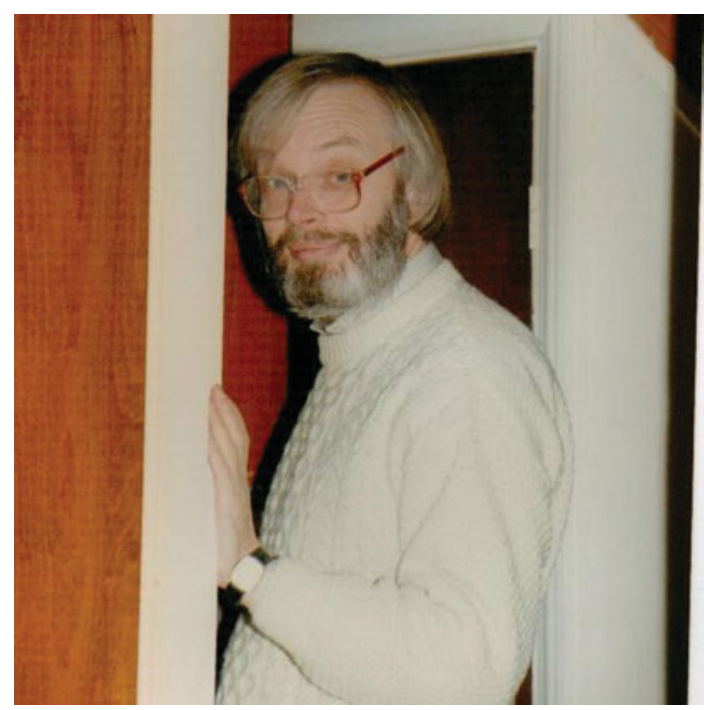

\section{Richard Wall - a bibliography}

\section{Edited books}

2001 (with Josef Ehmer and Tamara K. Hareven) Family History revisited: comparative perspectives. Revised edition of Historische Familienforschung. Debatten, Ergebnisse, Perspektiven, 1997 Campus.

1994 (with J. Henderson) Poor women and children in the European past, Routledge.

1988 (with J. Winter) The upheaval of war: family work and welfare in Europe, 1914-1918, Cambridge University Press. Reprinted 2005.

1983 (with J. Robin and P. Laslett) Family forms in historic Europe, Cambridge University Press. (Selected for Panel Discussion by the Social Science History Association Conference, 1984, Toronto). Italian edition, Forme di famiglia nella storia europea, Il Mulino, 1984.

1973/4 (Series editor) Pioneers of demography, 13 vols., Gregg International.

1972 (with P. Laslett) Household and family in past time, Cambridge University Press. 


\section{Contributions}

2009 'Gender based economic inequalities and women's perceptions of well-being in historical populations', in Bernard Harris, Lina Galvez and Helena Machado eds., Gender and well-being in europe, historical and contemporary perspectives, Ashgate.

2009 'Ideology and reality of the stem family in the writings of Frederic Le Play', in Antoinette Fauve-Chamoux and Emiko Ochiai eds., The stem family in Eurasian perspective, Peter Lang.

2005 'The quality of the master-servant relationship in Britain and the United States: the experience of a radical British visitor to the United States in the 1830s', in Suzy Pasleau and Isabelle Schopp eds., with Raffaellla Sarti, Servants and changes in mentality, 16th-20th centuries, vol. I, Les Éditions de l'Université de Liège.

2004 'The social and economic significance of servant migration', in Antoinette FauveChamoux ed., Domestic service and the formation of European identity. Understanding the globalisation of domestic work, 16th-21st centuries, Peter Lang. Also in Suzy Pasleau and Isabelle Schopp eds., with Raffaellla Sarti, Domestic service, a factor of social revival in Europe, vol. IV (2005), Les Éditions de l'Université de Liège.

2003 'Adoption', Oxford encyclopaedia of economic history.

2002 'Families in crisis and the English Poor Law', in Emiko Ochiai ed., The logic of female succession: rethinking patriarch and patrilineality in global and historical perspective, International Research Center for Japanese Studies.

2002 'The impact on the household of the death of the father in simple and stem family societies', in Renzo Derosas and Michel Oris eds., When dad died, Peter Lang.

2001 'The transformation of the European family across the centuries', in Richard Wall, Josef Ehmer and Tamara K. Hareven eds., Family history revisited: comparative perspectives, University of Delaware Press.

2001 'The household', in Encyclopedia of European social history, vol. 4, Charles Scribner's Sons.

2000 'The residence patterns of elderly English women in comparative perspective', in Lynn Bothelo and Pat Thane eds., Old women in England, 1500 to the present, Longman.

1998 'The stem family in the writings of Frédéric Le Play', in Antoinette Fauve-Chamoux and Emiko Ochiai eds., House and stem family in Eur Asian perspective, proceedings of $\mathrm{C} 18$ session, Twelfth International Economic History Congress.

1997 'Characteristics of European family and household systems', in Francisco Chacón Jininéz and Llorenc Ferrer I Alás eds., Familia, casa y trabajo, Universidad de Murcia.

1997 (with Antoinette Fauve) 'Nuptialite et famille', in J.-P. Bardet and J. Dupâquier eds., Histoire des populations de l'Europe, 1, Des origines aux prémices de la révolution démographique, Fayard.

1997 'Der Wandel der Familienstrukturen im Europa der Neuzeit', in Josef Ehmer, Tamara K. Hareven and Richard Wall eds., Historische Familienforschung. Debatten, Ergebnisse, Perspektiven, Campus.

1996 'Intergenerational relationships past and present', in Alan Walker ed., The new generational contract, UCL Press.

1995 'Fredeic Le Play e il lavoro femminile alla fine dell'Ottocento', in Giovanni Aliberti ed., L'Economia domestica, Istituti Editoriali e Poligrafici Internazionali.

1995 'Historical development of the household in Europe', in E. Van Imhoff, A. Kuijsten, P. Hooimeijer and L. van Wissen eds., Household demography and household modeling, Plenum. 
1995 'Elderly persons and members of their households in England and Wales from preindustrial times to the present', in D. Kertzer and P. Laslett eds., Aging in the past: demography, society and old age, University of California Press.

1994 'Some implications of the earnings, income and expenditure patterns of married women in populations in the past', in J. Henderson and R. Wall eds., Poor women and children in the European past, Routledge.

1992 'Relationships between the generations in British families past and present', in C. Marsh and S. Arber eds., Families and households: division and change, Macmillan. Also appeared as 'Les relations entre générations en Europe d'autrefois', Annales de démographie historique, 1991.

1991 'European family and household systems', in Société Belge de Démographie, Historiens et populations: liber amicorum Etienne Hélin, Academia, Louvain la Neuve.

1990 'Trabajo, bienstar y familia: una illustracion de la economia familiar adaptativa', in Bonfield et al. eds., El mundo que hemos qanada, Ministerio de trabajo.

1990 'International Symposium on family structure and population aging', in Zeng Yi, Zhang Chunyuan and Peng Songjian eds., Changing family structure and population aging in China, Peking University Press.

1989 'The place of the unskilled male worker in the economy of a nation: a comment', in P. Scholliers ed., Real wages in 19th and 20th century Europe: historical and comparative perspectives, Berg.

1989 'The residence patterns of the elderly in Europe in the 1980s', in E. Grebenik, C. Höhn and R. Mackenson eds., Later phases of the family life cycle: demographic aspects, Clarendon Press.

1989 'The living arrangements of the elderly in Europe in the 1980s', in W. Bytheway ed., Becoming and being old, Sage.

1988 'English and German families and the First World War 1914-1918', in R. Wall and J. Winter eds., The upheaval of war, Cambridge University Press.

1988 'Jükyü seiki ikö no jinköshi' (English population history in the nineteenth century), in O. Saito ed., Kazoku to jinkö no rekishi shakaigaku, Libro-poto, Tokyo.

1986 'Work, welfare and the family: an illustration of the adaptive family economy', in L. Bonfield, R. Smith and K. Wrightson eds., The world we have gained: histories of population and social structure, Blackwell, Oxford.

1986 'Arbeit, Fürsorge und Familie: Eine vergleichende Betrachtung von Handwerken, Bauern und Arbeitern in Devon und West Flandern', in M. Mitterauer and J. Ehmer eds., Familienstruktur und Arbeitsorganisation in Ländlichlichten Gesellschaften, Bölhau, Vienna.

1984 'Beyond the nuclear family', in CICRED, Demography of the family, Inter-Centre Co-operative Research Programme, Project 2, Final Report, Paris.

1984 'Real property, marriage and children: the evidence from four pre-industrial communities', in R. M. Smith ed., Land, kinship and life-cycle, Cambridge University Press.

1984 (with Kevin Schürer) 'Computing the history of the family: a question of standards', in F. Daelemans ed., Sources et méthodes de la démographie historique avant 1850, Archives et bibliotheques de Belgique. Also included in M. Thaller ed., Datenbanken und Datenverwaltungssysteme als Werkzeuge historischer Forschung, Scripta Mercaturae Verlag, 1986.

1983 'The household: demographic and economic change in England, 1650-1970', in R. Wall, J. Robin and P. Laslett eds., Family forms in historic Europe, Cambridge 
University Press. Also available in Japanese in O. Saito ed., Kazoku to jink $\ddot{o}$ no rekishi Shakaigaku, Libro-poto, Tokyo, 1988.

1983 'The composition of households in a population of 6 men to 10 women: south east Bruges in 1814', in R. Wall, J. Robin and P. Laslett eds., Family forms in historic Europe, Cambridge University Press.

1983 'Does owning real property influence the form of the household? An example from rural West Flanders', in R. Wall, J. Robin and P. Laslett eds., Family forms in historic Europe, Cambridge University Press.

1983 'Introduction', in R. Wall, J. Robin and P. Laslett eds., Family forms in historic Europe, Cambridge University Press.

1982 'Regional and temporal variations in the structure of the British household since 1851 ', in T. Barker and M. Drake eds., Population and society in Britain 1850-1980, Batsford Academic.

1977 'Regional and temporal variations in English household structure from 1650 ', in J. Hobcraft and P. Rees eds., Regional demographic development, Croom Helm.

1974 'Introduction', Slum conditions in London and Dublin, James Whitelaw (1798), Statistical Society of London (1848) and W. Quetelet (1848), reprinted by Gregg International.

1974 'Introduction', Mortality in mid-nineteenth century Britain, William Farr (1837) and Henry Ratcliffe (1850), reprinted by Gregg International.

1973 'Introduction', Comparative statistics in the nineteenth century, F. Bisset Hawkins (1829) and M. A. Quetelet (1842), reprinted by Gregg International.

1973 'Introduction', A comparative history of the increase and decrease of mankind in England and several countries abroad, Thomas Short (1767), reprinted by Gregg International.

1973 'Introduction', New observations on city, town and country bills of mortality, Thomas Short (1750), reprinted by Gregg International.

1972 'Mean household size in England from printed sources', in P. Laslett and R. Wall eds., Household and family in past time, Cambridge University Press.

\section{Articles}

2010 'Bequests to widows and their property in early modern England', The History of the Family 15(3), 222-38.

2010 'Economic collaboration of family members within and beyond households in English society 1600-2000', Continuity and Change 25(1), 83-108.

2009 'Relationships between the generations in British families past and present', Sociological Review of Kobe University 26, 52-73.

2007 (with Manon van den Heijden and Ariadne Schmidt) 'Broken families: economic resources of women who head families', The History of the Family 12(4), 223-32.

2007 'Widows and unmarried women as taxpayers in England before 1800', The History of the Family 12(4), 250-67.

2007 'Family relationships in comic postcards 1900-1930', The History of the Family 12(1), 50-61.

2006 'The contribution of the Poor Law in England towards alleviating the economic inequality of the elderly at the end of the eighteenth century', Revista de Demografia História XXIV, II, Segundo época, 135-54. 
2005 (with Antoinette Fauve) 'Domestic service in comparative perspective. Introduction', The History of the Family 10(4), 345-54.

2005 (with Matthew Woollard) 'Pre-1841 population census schedules and lists', Local Population Studies 74, 84-93.

2004 'English population statistics before 1800', The History of the Family 9(1), 81-95.

2002 'Introduction: widows: perceptions, demography, residence patterns, and standard of living', The History of the Family 7(1), 3-12.

2002 'Elderly widows and widowers and their coresidents in late 19th- and early 20th-century England and Wales', The History of the Family 7(1), 139-55.

2001 'The family circumstances of women migrating permanently or temporarily to Sundsvall in the nineteenth century', Scandinavian Economic History Review 49(3), 46-61.

2000 'La transformación de la familia Europea, siglos vvi-xx', Obradoiro de Historia Moderna 9, 7-41.

1999 'Beyond the household: marriage, household formation and the role of kin and neighbours', International Review of Social History 44, 55-67

1998 'Characteristics of European family and household systems', Historical Social Research 20(3), 44-66.

1996 'Marriage, residence and occupational choices of senior and junior siblings in the English past', The History of the Family: an International Quarterly 1(3), 259-71.

1996 (With P. Baizan and M. Lo Conte) 'Applying family and household typologies: some European comparisons', Proceedings of the European Population Conference, Milan.

1996 'Comparer ménages et familles au niveau Europeén: problèmes et perspectives', Population 51(1), 93-115.

1994 'The contribution of married women to the family economy under different family systems: some examples from the mid-nineteenth century from the work of Frédéric Le Play', Università Bocconi, Milan, Eleventh International Economic History Congress, pp. 139-48. Spanish translation in Boletín de la Asociación de Demografía Histórica XII (2/3), 185-97. Italian translation in Giovanni Aliberti ed., L'Economica domestica (secc. $X I X-X X)$, Istituti Editoriali e Poligrafici Internazionali, Pisa, Rome.

1994 'Diseguaglianze nel regime alimentare de bambini e bambine. Un'analisi comparata', Quaderni Storici XXIX, 91-116.

1994 'Einige Ungleichheiten bei Gesundheit und Ernährung von Knaben und Mädchen in England und Wales im 19. und 20. Jahrhundert', L'Homme 5, 94-126.

1993 (with E. Beekink) 'De levensloop van Adriana Meershoek: een korte studie op basis van het bevolkingsregister van Woerden, Barwoutswaarder en Rietveld', Heemtijdinghen 4, 104-15

1992 'Utilising the LS in historical and comparative studies', OPCS Longitudinal Study Newsletter, 6 May.

1991 'Le mode de cohabitation des personnes agées en France et en Angleterre', INSEE Méthodes 8. This paper appeared earlier in English as a City University LS Working Paper.

1991 'English and French households in historical perspective', INSEE Méthodes 8. This also appeared earlier as a City University LS Working Paper.

1990 'A Saida do lar o processo de foracao dos domicilios na Inglatea pre-industria', Estudos Economicos 20(1) January-April. A translation of 1987 Continuity and Change paper, 'Leaving home and the process of household formation'. 
1989 'Leaving home and living alone: an historical perspective', Population Studies 43(3), $369-89$.

1989 'Relationships within households in 1981', Population Trends 55.

1988 'The health of the schoolchild in the twentieth century', Local Population Studies 41.

1987 'Leaving home and the process of household formation in pre-industrial England', Continuity and Change 2(1), 77-101.

1986 'Beroeps-en gezinstrukturen: Brugge in het begin van de negentiende eeuw', Handelingen van het Genootschap Voor Geschiedenis te Brugge 123(1-2).

1984 'Residential isolation of the elderly: a comparison over time', Ageing and Society 4(4), 483-503.

1984 'The changing family', ESRC Newsletter $\mathbf{5 3}$.

1984 'Harnessing leisure to research: English local history', ESRC Newsletter 51.

1982 'The inhabitants of Summertown, Oxford, in the year 1832', Local Population Studies 28, 81-8.

1981 (with Brian Benson) 'Historical demography in the nineteenth and twentieth centuries in the absence of the civil registers', Local Population Studies 26, 14-28.

1981 'Inferring differential neglect of females from mortality data', Annales de Démographie Historique.

1981 'Women alone in English society', Annales de Démographie Historique.

1978 (with J. L. Flandrin) 'Les charactéristiques de la famille occidentale et leur ancienneté', Revue d'Histoire Moderne et Contemporaine XXV.

1978 (with Brian Benson) 'Vital statistics or medical statistics? Sources for the study of populations after 1837', Bulletin of the Society for the Social History of Medicine 23.

1978 'The age at leaving home', Journal of Family History 3(2), 181-202.

1978 'The historian and data tapes', Social History Society Newsletter 3(1).

1977 'Infant mortality in the 1890s', Local Population Studies 17, 48-50.

1976 'Reconstitution and census: Colytonians in parish register and enumerator's book', Exeter Papers in Economic History.

1972 'The use of scalograms', Local Population Studies 9.

1972 'The standardisation of census analysis', Local Population Studies 9.

\section{Working papers}

2004 Census Schedules and Listings, 1801-1831: an Introduction and Guide (with Matthew Woollard and Beatrice Moring), Department of History, University of Essex, Working Paper V.

1996 'Problems and perspectives in comparing household and family structures across Europe', Cambridge Group for the History of Population and Social Structure Working Paper Series: no. 3.

1990 'Residence patterns of the elderly in England and France', City University, London, LS Working Paper 69.

1990 'English and French households in historical perspective', City University, London, LS Working Paper 67.

1989 'Some inequalities in the raising of boys and girls in 19th and 20th century England and Wales', University of Minnesota, Humphrey Center Research Seminar on Population and Policy, Working Paper. 
1988 'Leaving home and living alone: an historical perspective', Centre for Economic Policy Research, Discussion Paper 211.

\section{In preparation}

\section{Books}

The welfare of widows in European society (with Beatrice Moring). Scheduled for completion 2011.

Peasants, artisans and labourers in nineteenth century Europe: essays on the time-budgets of Frédéric Le Play.

Papers

'Widows and their households in England 1600-1837'. To be submitted to Revue du Nord. 'Travail et temps libre dans les monographies familiales de Le Play'. To be submitted to Les Etudes Sociales.

'Housework and the labour market: working patterns of married women as reported in the time budgets of Frédéric Le Play'.

'Work time, work intensity and leisure time of peasants, artisans and labourers in the nineteenth century'. 